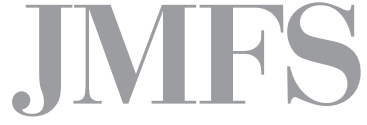

Journal of Management and Financial Sciences
Volume XI

Issue 34 (November 2018)

pp. $9-22$

Warsaw School of Economics

Collegium of Management and Finance

Sanjoy Ghose

University of Wisconsin-Milwaukee

Maria Johann

SGH Warsaw School of Economics

\title{
Measuring tourist satisfaction with destination attributes
}

\begin{abstract}
This study aims to contribute to the knowledge of value creation process in the tourism market by examining the impact of tourism product attributes on tourist satisfaction and tourist behavioural intentions. The research was conducted with 463 tourists visiting Poland. The research results show that several tour attributes and experience attributes influence tourist satisfaction and their willingness to recommend the country to others; however, drivers of satisfaction and recommendations, although often similar, were not always the same. Tour package features such as organization, attractiveness of the programme, and tour escort have a positive impact on both tourist satisfaction and recommendations. Moreover, some experience factors including tourist attractions - culture and monuments, and safety also have a positive impact on both tourist satisfaction and recommendations. Several managerial implications are outlined on the basis of the research results.
\end{abstract}

Keywords: tourism competitiveness, tourist satisfaction, tourism products, destination attributes, package holidays

JEL Classification Codes: L83, M31 


\section{Introduction}

Travel \& Tourism has emerged as one of the leading industries of the world and as one of the key drivers of growth among the service sectors. In total, travel \& tourism supported 313 million jobs (9.9\% of total employment) and generated 10.4\% of global GDP in 2017 [World Travel \& Tourism Council]. Tourism can bring many social and economic benefits and for many regions and countries is the most important source of welfare.

The direct contribution of travel \& tourism to GDP in Poland was $1.9 \%$ of total GDP in 2017 and it is forecast to rise by $4.7 \%$ pa from 2018 to 2028 to $2.4 \%$ of total GDP in 2028 . Travel \& tourism supported 332,000 jobs directly in 2017 (2.0\% of total employment) and this is forecast to grow by $2.9 \%$ pa to 448,000 of jobs in 2028 . This includes employment by hotels, travel agents, airlines and other passenger transportation services, the activities of the restaurant and leisure industries [World Travel \& Tourism Council].

Poland is not perceived as a typical tourist destination [Johann, 2014], however, it is worth mentioning that visitor exports are a key component of the direct contribution of travel \& tourism in Poland. In 2018, the country is expected to attract 19,670,000 international tourist arrivals and by 2028 , international tourist arrivals are forecast to total $25,534,000$, which is an increase of $5.3 \%$ pa [World Travel \& Tourism Council].

The increasing importance of tourism triggered interest in improving competitiveness of tourist destinations. Competitiveness of tourist destinations has also become a subject of great research interest over the last decades and many studies have focused on examining factors affecting destination competitiveness. There are different approaches towards defining, understanding, and measuring destination competitiveness. Among different concepts, one is that tourist satisfaction can be regarded as a destination competitiveness indicator.

This paper has three main objectives:

- to identify destination attributes that affect tourists'satisfaction related to their holiday experience in Poland;

- to determine the impact of destination attributes on satisfaction;

- to determine the impact of destination attributes on tourists' intention to recommend Poland as a tourist destination to others.

Information regarding tourists' perceptions of destination attributes is crucial for product managers to develop better suited packages for tourists and develop the communications strategy appealing to target customers. Moreover, data regarding tourists'satisfaction can be used as an important source of information for developing the communications strategy for the country, creating a desired brand image, and attracting more visitors. 


\section{Literature review}

There are numerous definitions of destination competitiveness. According to Dwyer \& Kim [2003] competitiveness of a destination refers to the capacity of the destination to provide tourists with goods and services better than its competitors. Hassan [2000] claims that a destination is competitive when it is able to create, integrate and deliver tourism experiences, including value-added goods and services important for tourists. Ritchie \& Crouch [2003] take a broader perspective and describe destination competitiveness as the ability to increase tourism expenditure and the number of visitors, provide tourists with satisfying and memorable experiences in a profitable way, increase the wellbeing of destination residents, and preserve the destination natural capital for future generations.

Dwyer \& Kim [2003] identified the main indicators of destination competitiveness and classified them in several groups. These include: endowed resources such as natural resources and cultural/heritage resources; created resources such as tourism infrastructure, a range of activities, shopping, entertainment, special events and festivals; supporting factors such as general infrastructure, quality of service, accessibility of a destination, hospitality, and market ties; destination management such as destination management organization, destination marketing management, destination policy, planning and development, human resources development, and environmental management; situational conditions such as competitive (micro) environment, destination location, global (macro) environment, price competitiveness, safety and security; demand fators such as destination awareness, perception and preferences; market performance indicators such as visitor statistics, contribution of tourism to the economy, indicators of tourism to the economy, indicators of economic prosperity, tourism investment, price competitiveness indices, and government support for tourism.

Destination competitiveness can be evaluated using quantitative and qualitative methods. A large number of variables could be used to assess destination competitiveness. These include objectively measured variables (i.e. tourist arrivals and tourism incomes) as well as subjectively measured variables which refer to tourists' evaluations of destination attributes. Moreover, both qualitative and quantitative measurement can be used when assessing destination competitiveness. [Kozak \& Rimmington, 1999]. Tourist satisfaction is very important because it is linked to destination choice [Ahmed, 1991], consumption of products and services, and a decision to revisit a given destination [Stevens, 1992; Kozak \& Rimmington, 2000]. Bernini \& Cagnone [2014] suggest that attribute-level conceptualization is desirable for analyzing tourist satisfaction with a destination.

Customer satisfaction has been examined in numerous empirical and conceptual studies and has been associated with service quality [Oliver, 1980; Parasuraman, Zeithaml \& Berry, 1985; Grönroos, 1990; Cronin \& Taylor, 1992]. The academic literature postulates that customer satisfaction results from a comparison between the customer's expectations and the performance of the product [Oliver, 1977; Churchill \& Surprenant, 1982; Tse \&Wilton, 1988; 
Yi, 1990, Vavra, 1997]. In the tourism context, there is also support for the impact of expectations on satisfaction, which has an influence on behavioural intentions [del Bosque \& San Martín, 2008]. It is evident that there is a relationship between experience quality, perceived value, satisfaction, and behavioural intentions [Chen \& Chen 2010]. Moreover, it is evident that tourist satisfaction with a destination is correlated with the destination's image and post-visit recollection of experiences [Chon, 1992]. The research results show that destination images have an impact on behavioural intentions and there is a path "destination image $\rightarrow$ trip quality $\rightarrow$ perceived value $\rightarrow$ satisfaction $\rightarrow$ behavioural intentions" [Chen $\&$ Tsai, 2007].

In this study the emphasis is put on the effects of the perceived value on satisfaction and behavioural intentions. We assume that tourist satisfaction depends on the overall holiday experience related to the fullfillment of tourists' needs with respect to destination attributes significant for travelers. Tourists may travel independently or on organized tours and their experience is shaped by different set of attributes. Those who travel independently experience a destination on the basis of their own choices, while package holiday travelers' experience is determined by the services offered by their tour operators as well as destination features.

Numerous studies provide evidence that satisfaction with tourism product attributes has an impact on tourists' behavioural intentions. The results show a significant effect of the perceived value on tourist satisfaction and their behavioural intentions [Pandža, 2015]; however, in the cruising industry, product attributes differ in terms of their impact on satisfaction and intention to recommend [Hosany \& Witham, 2010]. Moreover, research results suggest that future behaviour of tourists is determined by tour guide service and overall tourist satisfaction [Chan, Hsu \& Baum, 2015].

It can be stated also that tourists' overall experience related to package holidays is influenced by destination products and tourist company products [Mehmetoglu \& Normann, 2013]. This means that services provided by a tour operator as well as environmental factors should be regarded as tourist satisfaction determinants. Thus, the identification of destination attributes important for travellers is crucial for tourist satisfaction measurement as well as examination of their behavioural intentions.

\section{Research methodology}

\subsection{Questionnaire design}

The questionnaire was developed based on the findings from the literature, interviews, and discussions with experts as well as on the results from previous studies.

The questionnaire contained various types of questions, such as closed-ended questions on socio-demographic characteristics, customers' perception on tour package features and the different experiences that tourists had during their tourist visit, overall satisfaction, and willingness to recommend the tour, as well as open-ended questions where the visitors could 
express their opinions on holidays spent in Poland. The questionnaire was constructed using a 7-point scale.

The data was gathered from tourists who were spending their summer holidays on coach tours in Poland in 2014-2015. Package holidays were sold by tour operators and travel agents under their own brands in the USA, Canada, Australia, Spain, Portugal, Brazil and Mexico. Mazurkas Travel, Polish Incoming Tour Operator was responsible for all tour arrangements in Poland. The examined group of tourists participated in tours guided either in English or in Spanish/Portuguese. The tour itineraries included most important places and tourist attractions in Poland. The subjects were selected by convenience sampling from tours' participants. After each tour, the tourists received questionnaires in a pencil-and-paper form. The sample consisted of 463 valid questionnaires.

\subsection{Sample characteristics}

According to the survey results shown in Table $1,64.1 \%$ of the tourists were females and $35.9 \%$ males.

Table 1. Profile of the survey respondents

\begin{tabular}{|c|c|c|c|c|c|c|}
\hline \multicolumn{3}{|c|}{ Description } & \multirow{2}{*}{$\begin{array}{c}\text { Frequency } \\
297 \\
166 \\
463 \\
0 \\
463\end{array}$} & \multirow{2}{*}{$\begin{array}{r}\text { Percent } \\
64.1 \\
35.9 \\
100.0 \\
0.0 \\
100.0\end{array}$} & \multirow{2}{*}{$\begin{array}{c}\text { Valid Percent } \\
64.1 \\
35.9 \\
100.0\end{array}$} & \multirow{2}{*}{$\begin{array}{c}\text { Cumulative } \\
\text { Percent } \\
64.1 \\
100.0\end{array}$} \\
\hline Gender & $\begin{array}{l}\text { Valid } \\
\text { Missing } \\
\text { Total }\end{array}$ & $\begin{array}{l}\text { Female } \\
\text { Male } \\
\text { Total } \\
\text { System }\end{array}$ & & & & \\
\hline Age & $\begin{array}{l}\text { Valid } \\
\\
\text { Missing } \\
\text { Total }\end{array}$ & $\begin{array}{l}\text { under } 20 \\
21-30 \\
31-40 \\
41-50 \\
51-60 \\
61-70 \\
\text { over } 70 \\
\text { Total } \\
\text { System }\end{array}$ & $\begin{array}{r}11 \\
18 \\
20 \\
35 \\
88 \\
169 \\
78 \\
419 \\
44 \\
463\end{array}$ & $\begin{array}{r}2.4 \\
3.9 \\
4.3 \\
7.6 \\
19.0 \\
36.5 \\
16.8 \\
90.5 \\
9.5 \\
100.0\end{array}$ & $\begin{array}{r}2.6 \\
4.3 \\
4.8 \\
8.4 \\
21.0 \\
40.3 \\
18.6 \\
100.0\end{array}$ & $\begin{array}{r}2.6 \\
6.9 \\
11.7 \\
20.1 \\
41.1 \\
81.4 \\
100.0\end{array}$ \\
\hline $\begin{array}{l}\text { Country of } \\
\text { residence }\end{array}$ & $\begin{array}{l}\text { Valid } \\
\\
\text { Missing } \\
\text { Total }\end{array}$ & $\begin{array}{l}\text { United States } \\
\text { Spain } \\
\text { Australia } \\
\text { Canada } \\
\text { Brazil } \\
\text { Portugal } \\
\text { Argentina } \\
\text { Other countries } \\
\text { Total } \\
\text { System }\end{array}$ & $\begin{array}{r}260 \\
61 \\
48 \\
36 \\
17 \\
9 \\
4 \\
20 \\
455 \\
8 \\
463\end{array}$ & $\begin{array}{r}56.1 \\
13.2 \\
10.4 \\
7.8 \\
3.7 \\
1.9 \\
0.9 \\
4.3 \\
98.3 \\
1.7 \\
100.0\end{array}$ & $\begin{array}{r}57.1 \\
13.4 \\
10.6 \\
7.9 \\
3.7 \\
2.0 \\
0.9 \\
4.4 \\
100.0\end{array}$ & $\begin{array}{r}57.1 \\
70.5 \\
81.1 \\
89.0 \\
92.7 \\
94.7 \\
95.6 \\
100.0\end{array}$ \\
\hline
\end{tabular}

Source: Own study. 
When considering the visitors' age, they were represented by the following age groups: $2.4 \%$ under $20 ; 3.9 \%$ - between $21-30$ years old; $4.3 \%$ - between $31-40$ years old; $7.6 \%$ - between 41-50 years old; $19.0 \%$ - between $51-60$ years old; $36.5 \%$ - between $61-70$ years old; $16.8 \%$ - over 70. When taking into consideration the respondents' country of residence, they came from the following countries: $56.1 \%$ - the United States; $13.2 \%$ - Spain; $10.4 \%$ - Australia; 7.8\% - Canada, 3.7\% - Brazil, 1.9\% - Portugal; 0.9\% - Argentina; 4.3\% - other countries.

\subsection{Variables}

In the present research, we wanted to understand what kinds of variables might drive customer satisfaction. Therefore, as the major dependent variable, we focused on the information provided by the respondents to a question which asked about their level of satisfaction with their visit to Poland. While it was good to get an idea of the varying levels of satisfaction of the visitors to Poland, that did not provide information of much diagnostic value.

It was crucial to understand not only how satisfied they were but also much more important was to get some idea of what the reasons for their satisfaction were. Once we know the reasons, it would be possible for tour companies to tailor their offerings so that customer satisfaction would be enhanced.

We theorized that two categories of attributes were likely to influence satisfaction levels. One was closely related to the actual tour package features and the other was more related to the different experiences that the tourists had during their tourist visit. In our present research we thus concentrated on the respondents' perceptions about various attributes of these two categories.

While customer satisfaction is an indicator of how the visit went for these tourists, it is also managerially useful for tour operators to know how the touring experience might affect tourism in the future. With this in mind one of the other variables we considered was related to how likely the visitors were to recommend others visit Poland.

\subsection{Data analysis}

We wanted to identify which variables had a statistically significant effect on satisfaction and which of the significant variables had a greater impact on the same dependent variable. We therefore estimated the following model:

$$
\text { Satisfaction }=\beta_{0}+\beta_{1} x_{1}+\beta_{2} x_{2}+\ldots+\beta_{m} x_{m}+\epsilon_{1}
$$

where $\mathrm{m}=$ the number of actual tour package features, $\mathrm{x}$ are these features, and $\epsilon_{1}$ is the error term.

We next estimated the following model:

$$
\text { Satisfaction }=\gamma_{0}+\gamma_{1} z_{1}+\gamma_{2} z_{2}+\ldots+\gamma_{k} z_{k}+\epsilon_{2}
$$


where $\mathrm{k}=$ the number of tourist experienced features, $\mathrm{z}$ are these features, and $\epsilon_{2}$ is the error term.

After this we estimated the following models to capture the effects on tourist recommendations:

$$
\text { Recommendation }=\alpha_{0}+\alpha_{1} x_{1}+\alpha_{2} x_{2}+\ldots+\alpha_{m} x_{m}+\epsilon_{3}
$$

where $\mathrm{m}=$ the number of actual tour package features, $\mathrm{x}$ are these features, and $\epsilon_{3}$ is the error term

$$
\text { Recommendation }=\delta_{0}+\delta_{1} z_{1}+\delta_{2} z_{2}+\ldots+\delta_{m} z_{m}+\epsilon_{4}
$$

where $\mathrm{k}=$ the number of tourist experienced features, $\mathrm{z}$ are these features, and $\epsilon_{4}$ is the error term.

\subsection{Results}

From Table 2 we can observe that five out of the seven actual tour package features are strongly significant. These features are organization, attractiveness of the programme, restaurants and meals, hotels, and tour escort. All these five features had positive effects on tourist satisfaction. From the standardized coefficients in Table 2 it is evident that organization has the greatest impact on satisfaction, followed by that of the attractiveness of the programme.

Table 2. Statistical relationships between the actual tour package features and customers'

\begin{tabular}{|c|c|c|c|c|c|c|}
\hline \multicolumn{7}{|c|}{ Coefficients $^{a}$} \\
\hline & \multirow[t]{2}{*}{ Model } & \multicolumn{2}{|c|}{ Unstandardized Coefficients } & \multirow{3}{*}{$\begin{array}{c}\begin{array}{c}\text { Standardized } \\
\text { Coefficients }\end{array} \\
\text { Beta }\end{array}$} & \multirow[t]{2}{*}{$\mathrm{t}$} & \multirow[t]{2}{*}{ Sig. } \\
\hline & & B & Std. Error & & & \\
\hline \multirow[t]{8}{*}{1} & (Constant) & 1.406 & .307 & & 4.588 & .000 \\
\hline & Attractiveness of the program & .206 & .041 & .234 & 4.995 & .000 \\
\hline & Organization & .275 & .042 & .297 & 6.477 & .000 \\
\hline & Hotels & .110 & .032 & .141 & 3.390 & .001 \\
\hline & Restaurants and meals & .107 & .030 & .157 & 3.533 & .000 \\
\hline & Standard of the bus & -.036 & .033 & -.046 & -1.110 & .268 \\
\hline & Tour escort & .126 & .048 & .106 & 2.608 & .009 \\
\hline & Price/quality relationship & .008 & .044 & .009 & .173 & .863 \\
\hline
\end{tabular}
satisfaction with their visit to Poland

a. Dependent variable: General satisfaction with your visit.

Source: Own study.

Next, we illustrate how a typical independent variable from the above table (Table 2) affects the mean satisfaction level of the respondents; we do this by using a graph. Below in Figure 1, we show the effect of the hotels variable on customer satisfaction. The graph confirms that 
as the respondents' perceptions of hotels improves from poor to excellent, the mean overall satisfaction level with their visit also increases.

Figure 1. Impact of the perceptions of hotels on customers' satisfaction with their visit to Poland
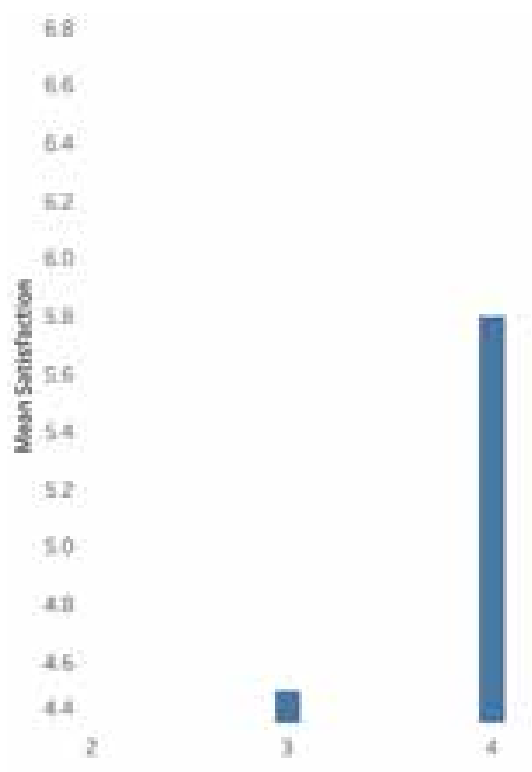

Source: Own study.

Table 3 indicates that four out of the thirteen experience aspects of the tourists' visit to Poland had strong statistically significant effects on satisfaction. The greatest impact came from tourist attractions - culture and monuments, followed by safety, nature/countryside and climate of stay, in that order. It is interesting to note that while tourist attractions, climate of stay and safety each had a positive effect, nature/countryside had a negative effect on satisfaction. In addition, the weather and the possibility of communicating in English had marginally significant effects on satisfaction.

Table 3. Statistical relationships between experience aspects of the tourists' visit and customers' satisfaction with their visit to Poland

\begin{tabular}{|c|c|c|c|c|c|c|}
\hline \multicolumn{7}{|c|}{ Coefficients $^{\mathrm{a}}$} \\
\hline \multirow{2}{*}{\multicolumn{2}{|c|}{ Model }} & \multicolumn{2}{|c|}{ Unstandardized Coefficients } & \multirow{3}{*}{$\begin{array}{c}\text { Standardized } \\
\text { Coefficients } \\
\text { Beta }\end{array}$} & \multirow[t]{2}{*}{$\mathrm{t}$} & \multirow[t]{2}{*}{ Sig. } \\
\hline & & B & Std. Error & & & \\
\hline \multirow[t]{5}{*}{1} & (Constant) & 2.247 & .276 & & 8.147 & .000 \\
\hline & Climate, atmosphere of your stay & .083 & .041 & .113 & 2.047 & .041 \\
\hline & Tourist attractions & .418 & .052 & .456 & 8.021 & .000 \\
\hline & Nature, countryside & -.102 & .039 & -.130 & -2.655 & .008 \\
\hline & Shopping opportunities & .027 & .034 & .041 & .787 & .432 \\
\hline
\end{tabular}




\begin{tabular}{|l|l|c|c|c|c|c|}
\hline & Safety & .169 & .050 & .172 & 3.403 & .001 \\
\cline { 2 - 7 } & Opportunity to meet new people & -.014 & .033 & -.022 & -.422 & .673 \\
\cline { 2 - 7 } & Entertainment & .023 & .034 & .035 & .668 & .505 \\
\cline { 2 - 7 } & Weather & -.049 & .029 & -.084 & -1.700 & .090 \\
\cline { 2 - 7 } & Cleanliness & -.037 & .052 & -.038 & -.710 & .478 \\
\cline { 2 - 7 } & Reasonable prices & .040 & .048 & .046 & .841 & .401 \\
\cline { 2 - 7 } & Tourist information & .021 & .048 & .023 & .437 & .662 \\
\cline { 2 - 6 } & Kindness to foreigners & .020 & .040 & .027 & .621 & .098 \\
\cline { 2 - 6 } & Possibility to communicate in English & .055 & .033 & .084 & 1.656 & \\
\hline
\end{tabular}

a. Dependent variable: General satisfaction with your visit. Source: Own study.

Below in Figure 2 we illustrate with a graph that as the customers' perceptions of tourist attractions - culture and monuments increase from average to excellent, their mean satisfaction score also increases - thus, confirming the analytical result indicated above in Table 3.

Figure 2. Impact of the perceptions of tourist attractions on customers' satisfaction with their visit to Poland

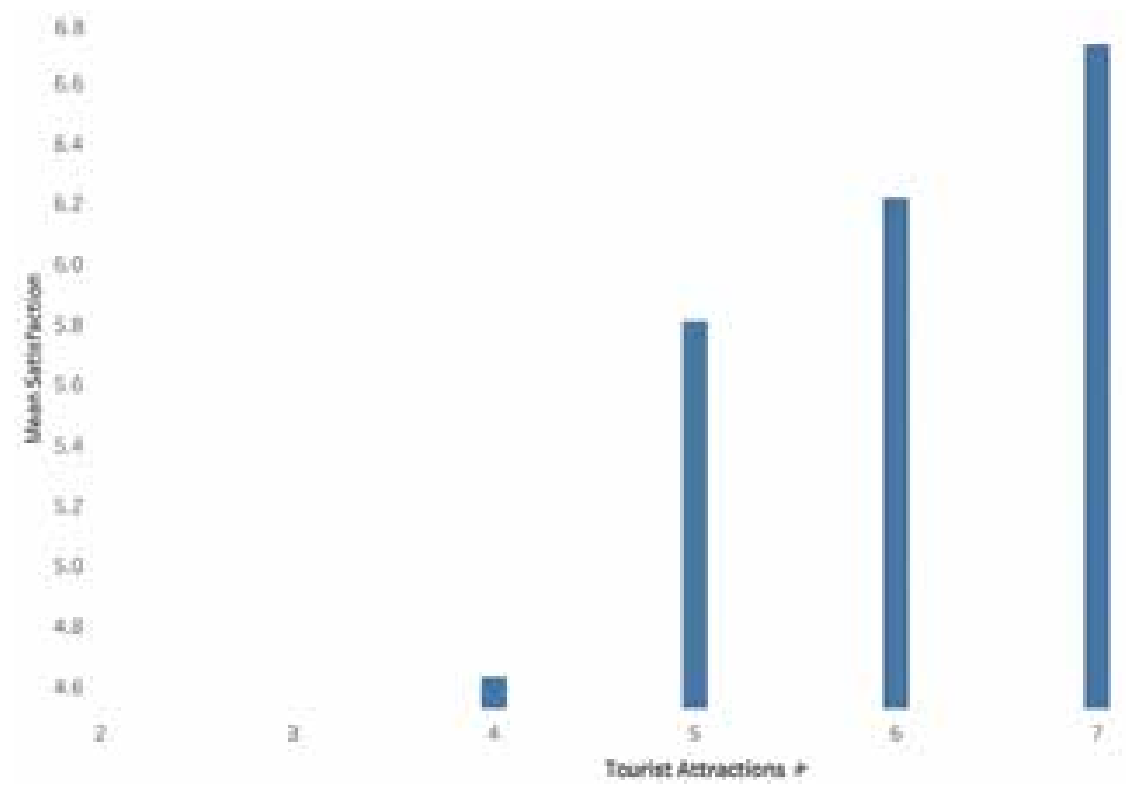

Source: Own study.

From Table 4, it can be seen that three out of the seven actual tour package features had significant and positive impacts on tourist recommendations. Attractiveness of the programme had the greatest impact followed by tour escort and organization. It is interesting to observe that restaurants and meals, as well as hotels did not have any significant effect on recommendations to visit Poland while they did have effects on satisfaction with the tourists' own visit in Poland. 
Table 4. Statistical relationships between actual tour package features and customers' recommendations about their visit to Poland

\begin{tabular}{|c|c|c|c|c|c|c|}
\hline \multicolumn{7}{|c|}{ Coefficients $^{\mathrm{a}}$} \\
\hline & \multirow[t]{2}{*}{ Model } & \multicolumn{2}{|c|}{ Unstandardized Coefficients } & \multirow{3}{*}{$\begin{array}{c}\text { Standardized } \\
\text { Coefficients } \\
\text { Beta }\end{array}$} & \multirow[t]{2}{*}{$\mathrm{t}$} & \multirow[t]{2}{*}{ Sig. } \\
\hline & & B & Std. Error & & & \\
\hline \multirow[t]{8}{*}{1} & (Constant) & 3.086 & .324 & & 9.519 & .000 \\
\hline & Attractiveness of the program & .188 & .044 & .240 & 4.320 & .000 \\
\hline & Organization & .084 & .045 & .102 & 1.873 & .062 \\
\hline & Hotels & .039 & .034 & .056 & 1.142 & .254 \\
\hline & Restaurants and meals & .044 & .032 & .073 & 1.381 & .168 \\
\hline & Standard of the bus & .042 & .035 & .060 & 1.193 & .233 \\
\hline & Tour escort & .128 & .051 & .121 & 2.511 & .012 \\
\hline & Price/quality relationship & .035 & .048 & .044 & .740 & .460 \\
\hline
\end{tabular}

a. Dependent variable: Do you recommend visiting Poland? Source: Own study.

The following graph shows that as the perception of the attractiveness of the programme increases from average to excellent, the mean recommendation score also increases - confirming the relationship shown from the statistical analysis results in Table 4.

Figure 3. Impact of the perceptions of the attractiveness of the tour programme on customers' recommendations about their visit to Poland

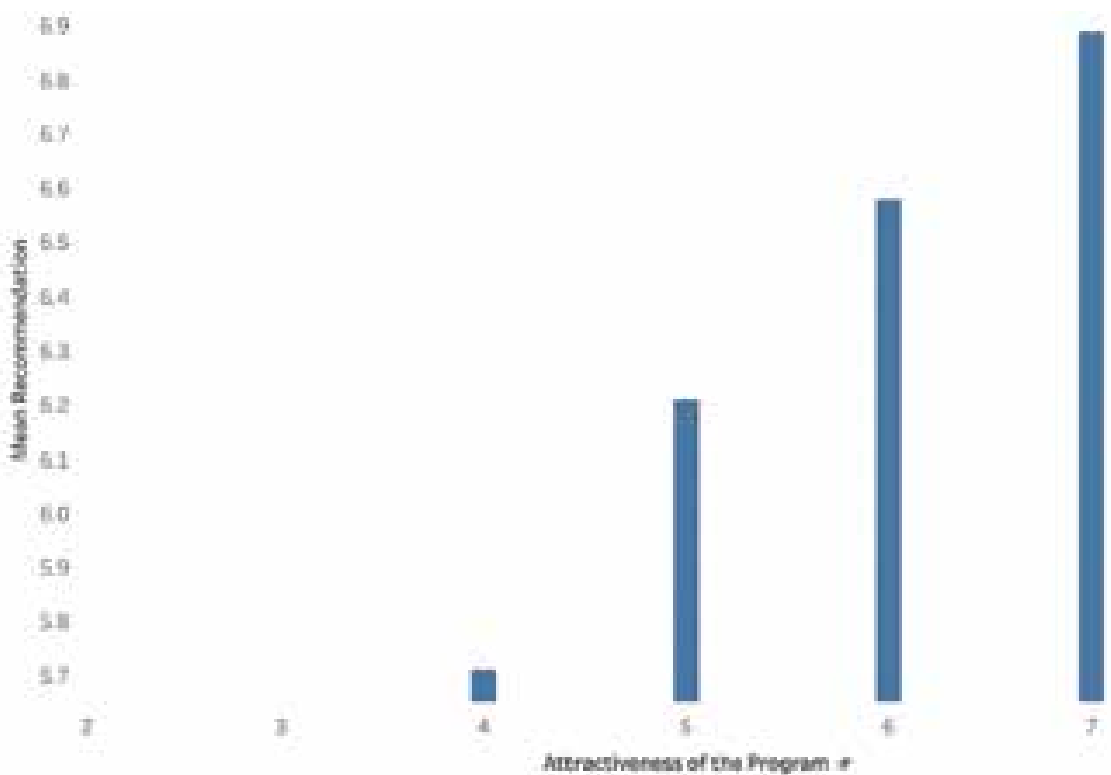

Source: Own study. 
Table 5 shows that tourist attractions - culture and monuments have the highest impact on recommendations, and the impacts are positive. It is clear from the table that tourists had a positive perception of safety and this resulted in a positive effect on their recommendations; the effect of safety was second only to that of tourist attractions. kindness to foreigners, the weather and cleanliness also significantly affected the recommendations.

Table 5. Statistical relationships between The experience aspects of the tourists' visit and customers' recommendations about their visit to Poland

\begin{tabular}{|c|c|c|c|c|c|c|}
\hline \multicolumn{7}{|c|}{ Coefficients $^{\mathrm{a}}$} \\
\hline \multirow{2}{*}{\multicolumn{2}{|c|}{ Model }} & \multicolumn{2}{|c|}{ Unstandardized Coefficients } & \multirow{3}{*}{$\begin{array}{c}\text { Standardized } \\
\text { Coefficients } \\
\text { Beta }\end{array}$} & \multirow[t]{2}{*}{$\mathrm{t}$} & \multirow{2}{*}{ Sig. } \\
\hline & & B & Std. Error & & & \\
\hline \multirow[t]{14}{*}{1} & (Constant) & 3.353 & .265 & & 12.632 & .000 \\
\hline & Climate, atmosphere of your stay & .031 & .040 & .047 & .789 & .431 \\
\hline & Tourist attractions & .247 & .050 & .303 & 4.921 & .000 \\
\hline & Nature, countryside & .058 & .037 & .083 & 1.575 & .116 \\
\hline & Shopping opportunities & -.013 & .033 & -.023 & -.410 & .682 \\
\hline & Safety & .125 & .048 & .142 & 2.600 & .010 \\
\hline & Opportunity to meet new people & -.013 & .032 & -.023 & -.418 & .676 \\
\hline & Entertainment & .011 & .032 & .019 & .332 & .740 \\
\hline & Weather & -.060 & .028 & -.115 & -2.169 & .031 \\
\hline & Cleanliness & -.100 & .050 & -.117 & -2.006 & .045 \\
\hline & Reasonable prices & .049 & .046 & .063 & 1.056 & .292 \\
\hline & Tourist information & .066 & .046 & .083 & 1.442 & .150 \\
\hline & Kindness to foreigners & .091 & .039 & .138 & 2.331 & .020 \\
\hline & Possibility to communicate in English & .022 & .032 & .038 & .698 & .486 \\
\hline
\end{tabular}

a. Dependent variable: Do you recommend visiting Poland? Source: Own study.

The graphical analysis in Figure 4 below confirms the relationship shown in the statistical analysis results shown above in Table 5; the graph depiction indicates that as the perceptions of safety of the respondents increase from average to excellent, their mean recommendation score also increases. 
Figure 4. Impact of the perceptions of safety on customers' recommendations about their visit to Poland

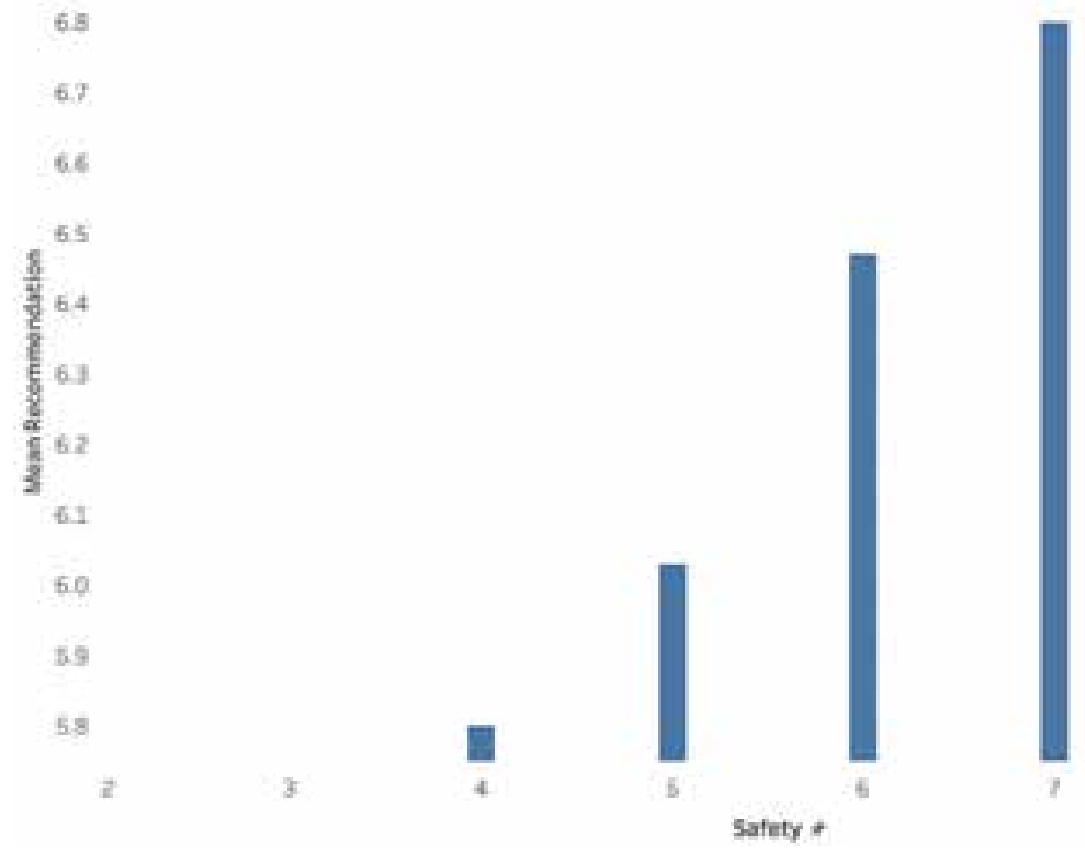

Source: Own study.

\section{Summary}

Tourism is a very important service sector in many parts of the world. In this paper we have examined what kinds of attributes motivate tourists to feel satisfied with their trip to Poland and also what motivates the same tourists to make recommendations to others to visit Poland. Drivers of satisfaction and recommendations, although often similar, were not always the same. For instance, hotels, and restaurant and meals affected the tourists' own satisfaction but did not affect the likelihood of making recommendations to others. Similarly, the climate/atmosphere of their stay, and nature/countryside affected their satisfaction but not recommendations. Our study, therefore, provides important diagnostic information to the tourism industry in Poland.

The research results enabled to better understand tourist satisfaction drivers and formulate appropriate recommendations regarding Polish tour operators' marketing strategy for the distinguished markets.

Tour package features such as organization, attractiveness of the programme, and tour escort have a positive impact on both tourist satisfaction and recommendations, thus it is important to put an emphasis on those attributes while developing tourist products. Moreover, some experience factors including tourist attractions - culture and monuments as well as 
safety have also a positive impact on both tourist satisfaction and recommendations, which means that they are crucial when developing tour itineraries. Those attributes that affect tourist satisfaction and recommendations should also be highlighted in the tour operators' communications strategy.

Moreover, the information gathered from the research is useful for the development of marketing strategy for Poland as a tourist destination. Those attributes which affect tourist satisfaction and recommendations could be used in the communications strategy for the country in the distinguished markets. It is highly important because the communications strategy is crucial for creating the country's desired brand image and promoting its tourist attractiveness.

\section{Limitations and future scope of the research}

This study has considered package holiday travelers' satisfaction and behavioural intentions with regard to their visit to Poland. The cultural, social, psychological and personal characteristics of tourists have not been taken into consideration in this study. Only after doing this can one consider respondents' opinions to be fully reflective as representatives of individual countries. Moreover, the analysis of the research outcomes is based on package vacation tourists from selected countries. Hence, conclusions can be limited to the distinguished groups of tourists. For future reference, a survey could be carried out across cultures in order to overcome the above-mentioned limitations.

\section{References}

1. Ahmed, Z.U., 1991. The influence of the components of a state's tourist image on product positioning strategy. Tourism Management, 12(4), pp. 331-340.

2. Bernini, C., \& Cagnone, S., 2014. Analysing tourist satisfaction at a mature and multi-product destination. Current Issues in Tourism, 17(1), pp. 1-20.

3. Chan, A., Hsu, C.H., \& Baum, T., 2015. The impact of tour service performance on tourist satisfaction and behavioral intentions: A study of Chinese tourists in Hong Kong. Journal of Travel \& Tourism Marketing, 32(1-2), pp. 18-33.

4. Chen, C.F., \& Tsai, D., 2007. How destination image and evaluative factors affect behavioral intentions? Tourism Management, 28(4), pp. 1115-1122.

5. Chen, C.F., \& Chen, F.S., 2010. Experience quality, perceived value, satisfaction and behavioral intentions for heritage tourists. Tourism Management, 31(1), pp. 29-35.

6. Chon, K.S., 1992. The role of destination image in tourism: An extension. The Tourist Review, 47(1), pp. 2-8.

7. Churchill G.A. Jr., \& Surprenant, C., 1982. An investigation into the determinants of customer satisfaction. Journal of Marketing Research, 19, pp. 491-504.

8. Cronin J.J. Jr., \& Taylor, S.A., 1992. Measuring service quality: a reexamination and extension. The Journal of Marketing, pp. 55-68. 
9. del Bosque, I.R., \& San Martín, H., 2008. Tourist satisfaction a cognitive-affective model. Annals of Tourism Research, 35(2), pp. 551-573.

10. Dwyer, L., \& Kim, C., 2003. Destination competitiveness: determinants and indicators. Current Issues in Tourism, 6(5), pp. 369-414.

11. Grönroos, C., 1990. Relationship approach to marketing in service contexts: The marketing and organizational behavior interface. Journal of Business Research, 20(1), pp. 3-11.

12. Hassan, S.S., 2000. Determinants of market competitiveness in an environmentally sustainable tourism industry. Journal of Travel Research, 38(3), pp. 239-245.

13. Hosany, S., \&Witham, M., 2010. Dimensions of cruisers' experiences, satisfaction, and intention to recommend. Journal of Travel Research, 49(3), pp. 351-364.

14. Johann, M., 2014. The image of Poland as a tourist destination. European Journal of Tourism, Hospitality and Recreation, 5, pp. 143-161.

15. Kozak, M., \& Rimmington, M., 1999. Measuring tourist destination competitiveness: conceptual considerations and empirical findings. International Journal of Hospitality Management, 18(3), pp. 273-283.

16. Kozak, M., \& Rimmington, M., 2000. Tourist satisfaction with Mallorca, Spain, as an off-season holiday destination. Journal of Travel Research, 38(3), pp. 260-269.

17. Mehmetoglu, M., \&Normann, Ø., 2013. What influences tourists' overall holiday experience? Tourism company products versus destination products. European Journal of Tourism Research, 6(2), p. 183.

18. Oliver, R.L., 1977. Effect of expectation and disconfirmation on postexposure product evaluations: An alternative interpretation. Journal of Applied Psychology, 62 (4), p. 480.

19. Oliver, R.L., 1980. A cognitive model of the antecedents and consequences of satisfaction decisions. Journal of Marketing Research, 17(11), pp. 460-469.

20. Pandža Bajs, I., 2015. Tourist perceived value, relationship to satisfaction, and behavioral intentions: The example of the Croatian tourist destination Dubrovnik. Journal of Travel Research, 54(1), pp. 122-134.

21. Parasuraman, A., Zeithaml, V.A., \& Berry, L.L., 1985. A conceptual model of service quality and its implications for future research. Journal of Marketing, 49(3), pp. 41-50.

22. Ritchie, J.B., \& Crouch, G.I., 2003. The competitive destination: A sustainable tourism perspective. Cambridge, MA: CABI Publishing.

23. Stevens, B.F., 1992. Price value perceptions of travelers. Journal of Travel Research, 31(2), pp. $44-48$.

24. Tse, D.K., \&Wilton, P.C., 1988. Models of consumer satisfaction formation: An extension. Journal of Marketing Research, 25(2), pp. 204-212.

25. World Travel \& Tourism Council, http://wttc.org, [accessed: 10.03.2018].

26. Vavra, T.G., 1997. Improving your measurement of customer satisfaction: A guide to creating, conducting, analyzing, and reporting customer satisfaction measurement programs. ASQ Quality Press, Milwaukee.

27. Yi, Y., 1990. A critical review of consumer satisfaction. Review of Marketing, 4(1), pp. 68-123. 